\title{
Prolactin enhances uteroglobin gene expression by uteri of immature rabbits*
}

\author{
G. W. Randall§, J. C. Daniel, Jr† and B. S. Chilton $\ddagger$ \\ Andrology Laboratory, Bristol Regional Medical Center, Bristol, Tennessee 37623, USA; \\ $\dagger$ College of Sciences, Old Dominion University, Norfolk, Virginia 23508, USA; and \\ $\ddagger$ Department of Cell Biology \& Anatomy, Texas Tech University Health Sciences Center, Lubbock, \\ Texas 79430, USA
}

\begin{abstract}
Summary. The effect of prolactin on uteroglobin production by immature rabbits was studied with neonatal ( 1 day old) and juvenile ( 14 days old) does. The animals were divided into 11 treatment groups for each age category and exposed to a 9-day injection protocol. Each day the animals received a subcutaneous injection of oestradiol-17 $\beta$ and/or ovine prolactin and/or progesterone, or were sham-injected. Juvenile animals, which received $100 \mu \mathrm{g}$ oestradiol $/ \mathrm{kg} 24 \mathrm{~h}^{-1}$, plus progesterone or plus prolactin and progesterone, produced detectable amounts of uteroglobin in the uterine secretions $(0.034 \pm 0.010 \mathrm{mg}$ uteroglobin $/ \mathrm{mg}$ total protein and $0.098 \pm 0.031 \mathrm{mg}$ uteroglobin $/ \mathrm{mg}$ total protein, respectively). None of the animals in the other juvenile treatment groups or any of the neonatal groups produced uteroglobin.

From this survey it was apparent that uteroglobin secretion could be induced by exogenous oestradiol and progesterone in rabbits treated as early as 14 days of age, and that the added supplementation of prolactin enhanced the response to the ovarian steroids. As a result, additional juvenile animals were injected with $100 \mu \mathrm{g}$ oestradiol \pm prolactin + progesterone and the effects of these two treatments were quantitated as follows: uteroglobin mRNA levels by slot-blot hybridization; endometrial surface area by computerized image analysis; and oestrogen, progesterone and prolactin receptors by immunocytochemistry. Prolactin modified the response of the juvenile rabbit uterus to oestradiol + progesterone for all parameters tested.
\end{abstract}

Keywords: prolactin; uteroglobin; immunocytochemistry; receptors; rabbit

\section{Introduction}

That a dynamic relationship exists between prolactin and steroid hormones in the reproductive tract of female mammals is sustained by several facts. For instance, prolactin increases the oestradiol receptor content of rat granulosa cells (Gibori et al., 1979), and oestradiol increases prolactin binding in pig granulosa cells (Hammond \& Krall, 1979). Moreover, prolactin causes endometrial hypertrophy and glandular differentiation (Chilton \& Daniel, 1985), and increases the concentration of progesterone receptor (Daniel et al., 1984; Chilton \& Daniel, 1987) in rabbit uterine endometrium. In this tissue, progesterone, acting through its receptor, promotes the expression of prolactin receptor (Chilton et al., 1988). When long-term ovariectomized rabbits are treated sequentially with various doses of prolactin plus progesterone $(3 \mathrm{mg} / \mathrm{kg})$ uteroglobin mRNA increases in a dose-dependent manner, exceeding the value for progesterone treatment alone (Chilton et al., 1988). The amount of uteroglobin mRNA correlated well with the amount of

*Reprint requests to Dr Joseph C. Daniel, Jr.

§Present address: Andrology Laboratory, Indian Path Medical Center, Kingsport, TN 37660, USA. 
secreted uteroglobin (Daniel et al., 1988), suggesting that prolactin synergizes with progesterone in regulating uteroglobin gene transcription. Collectively, these data supported the proposal of a servomechanism in which prolactin and progesterone increase each other's receptor and thereby interact to regulate uteroglobin gene expression (Chilton et al., 1988). The servomechanism predicts that the greatest amount of uteroglobin would be produced by rabbits treated sequentially with progesterone to induce prolactin receptor expression, then with prolactin to increase progesterone receptor expression, and finally with progesterone. Using this treatment protocol, Daniel \& Juneja (1989) demonstrated a 2-fold increase in the concentration of uteroglobin over animals treated with prolactin + progesterone, supporting the efficacy of the prolactin-progesterone interaction.

In juvenile rabbits there is an increase in both total and unoccupied prolactin receptors between 2 and 4 weeks of age, presumably increasing uterine sensitivity to prolactin during development (Chilton et al., 1988). The purposes of this study were (1) to determine whether prolactin administration alters the time of onset or enhances the magnitude of uteroglobin secretion by the uteri of immature rabbits in response to progesterone alone or in combination with oestradiol; (2) to correlate changes in uteroglobin protein content with uteroglobin mRNA levels; and (3) to evaluate the effects of selective treatments on uterine endometrial histology and the expression of hormone (oestrogen, progesterone and prolactin) receptors in specific regions of the developing uterus.

\section{Materials and Methods}

Animals and their maintenance. To provide the young rabbits used in this study, adult females were mated to fertilityproven males. They were maintained on rabbit chow (Purina) and tap water, provided ad libitum, in a 14-h light-10-h dark photoperiod. Nesting boxes were added to each cage on Day 28 post coitum and each litter constituted an injection group. Young were removed daily for treatment but otherwise were left with the mother.

A virgin female goat, 10 months of age, was used for antiserum production. She was kept in pasture for the duration of the experiment with shelter available, and fresh grain (Formax) and tap water provided ad libitum.

Rabbit treatment protocols. Two groups of rabbits received 9 days of daily injections of one or more of the hormones oestradiol-17ß ovine prolactin or progesterone or their carriers alone to provide sham treatment, according to the schedule presented in Table 1. The first group was composed of neonates for which the injection protocol began on the 1st day after birth. For the second group, designated as juveniles, the injections began on Day 14 after birth. Hormones, or carriers, were administered as suprascapular subcutaneous injections delivered at 10:00 h daily. Hormones were purchased from Sigma Chemical Company (St Louis, MO, USA). Corn oil or 0.1 M-phosphatebuffered $-0.9 \%(\mathrm{w} / \mathrm{v}) \mathrm{NaCl}$ (PBS), $\mathrm{pH} 7.2$, comprised carrier solutions for the steroids and prolactin, respectively, and were used for sham injections in the experimental protocol.

Collection of uterine flushings. At $2 \mathrm{~h}$ after the final injection, the rabbits (then 9 and 22 days old) were killed by cervical dislocation. Uterine horns were excised through a mid-ventral incision, rinsed with PBS, blotted and flushed with $0.2 \mathrm{ml}$ PBS. Each flushing was transferred to a microcentrifuge tube (Eppendorf) containing $1 \mu \mathrm{l} \%$ phenylmethylsulphonyl fluoride (protease inhibitor) in PBS and centrifuged $(5000 \mathrm{~g})$ for $5 \mathrm{~min}$ to remove cellular debris. Then $50 \mu \mathrm{l}$ samples of the supernatant were transferred to microcentrifuge tubes, frozen in an acetone and solid $\mathrm{CO}_{2}$ slurry and stored at $-20^{\circ} \mathrm{C}$ until assayed for uteroglobin.

Isolation of uteroglobin. Six mature female rabbits $(3.5-4.5 \mathrm{~kg}$ each) were given intravenous injections of $100 \mathrm{i} . \mathrm{u}$. hCG in $0.1 \mathrm{ml}$ PBS to induce pseudopregnancy. On Day 5 after injection, the rabbits were killed, their uteri explanted and each uterine horn flushed with $5 \mathrm{ml}$ PBS. Uteroglobin was isolated from the flushing by molecular sieving through Sephadex G200 and Sephadex G50 columns as described by Daniel (1976). The fractions containing uteroglobin were dialysed against distilled water for $6 \mathrm{~h}$ at $4^{\circ} \mathrm{C}$ and lyophilized to dryness.

Production and characterization of goat anti-uteroglobin antiserum. An antiserum to the above purified uteroglobin was prepared in a 10 -month-old female goat. The immunization procedure was similar to that described by Johnson $e t$ al. (1972). Four suprascapular immunization sites were shaved. Blood collection sites were similarly exposed along each forelimb over the anterior subcutaneous vein. Preimmune blood was also collected from these veins. Each suprascapular injection site was swabbed with ethanol and injected intradermally with $0.5 \mathrm{mg}$ uteroglobin in $500 \mu \mathrm{l}$ Freund's Adjuvant (Difco Labs, Detroit, MI, USA).

Injections were administered every 2 weeks for 8 weeks. Incomplete adjuvant was used for preparation of all but the initial injection solution. The injection series was followed by blood collection for 9 weeks to determine the optimal time of immune responsiveness. The serum collection which yielded the highest titre of goat anti-uteroglobin antiserum, as determined by Ouchterlony immunodiffusion analysis, was used in the experimental procedure. The 
Table 1. Sequential hormone administration to rabbits beginning on Day 1 or Day 9 after birth

\begin{tabular}{|c|c|c|c|c|}
\hline Group & $\begin{array}{c}10 \mu \mathrm{g} \\
\text { oestradiol/ } \\
\mathrm{kg} 24 \mathrm{~h}^{-1}\end{array}$ & $\begin{array}{c}100 \mu \mathrm{g} \\
\text { oestradiol// } \\
\mathrm{kg} 24 \mathrm{~h}^{-1}\end{array}$ & $\begin{array}{c}14 \text { i.u. } \\
\text { prolactin*/ } \\
\text { kg } 24 \mathrm{~h}^{-1}\end{array}$ & $\begin{array}{c}3 \mathrm{mg} \\
\text { progesterone } / \mathrm{kg} \\
24 \mathrm{~h}^{-1}\end{array}$ \\
\hline$\stackrel{1}{\text { (control) }}$ & Sham & - & Sham & Sham \\
\hline 2 & + & - & Sham & Sham \\
\hline 3 & + & - & + & Sham \\
\hline 4 & + & - & + & + \\
\hline 5 & + & - & Sham & + \\
\hline 6 & - & + & Sham & Sham \\
\hline 7 & - & + & + & Sham \\
\hline 8 & - & + & + & + \\
\hline 9 & - & + & Sham & + \\
\hline 10 & Sham & - & + & Sham \\
\hline 11 & Sham & - & + & + \\
\hline 12 & Sham & - & Sham & + \\
\hline \multicolumn{5}{|l|}{ Treatment } \\
\hline Day & 1,2 & 1,2 & $3,4,5$ & $6,7,8,9$ \\
\hline
\end{tabular}

+ , received described treatment; - , no treatment given; sham, received carrier alone.

Each animal received a $0 \cdot 1 \mathrm{ml}$ injection as indicated on each of 9 injection days.

$* 14$ i.u. $=0.5 \mathrm{mg}$ prolactin.

antiserum was absorbed with pooled serum from oestrous rabbits to remove non-specific activity and standardized against known concentrations of uteroglobin.

Detection and quantitation of uteroglobin. The presence and relative amounts of uteroglobin in uterine flushings from young rabbits were determined by the one-dimensional immunodiffusion procedure in Oudin tubes as described by Crowle (1973) and modified by Daniel et al. $(1984,1988)$. Also, two-dimensional immunoelectrophoretic analysis, as described by Crowle (1973), was used to verify that the goat anti-uteroglobin antiserum was monospecific.

Total protein concentration in uterine flushings was determined by the method of Lowry et al. (1951), using duplicate $20 \mu \mathrm{l}$ samples of neonatal and juvenile rabbit uterine flushings. Results were expressed as $\mathrm{mg}$ uteroglobin/mg total protein.

Light microscopy. Small pieces $\left(1 \mathrm{~mm}^{3}\right)$ of whole uterine tissue were fixed overnight in $0.1 \mathrm{M}$-cacodylate-buffered $(\mathrm{pH} 7.35) 3 \%$ glutaraldehyde at $4^{\circ} \mathrm{C}$. Tissues were post-fixed with $2 \%$ osmium tetroxide, dehydrated and embedded in Epon 812 (Luft, 1961). Thick sections $(1 \mu \mathrm{m}$ ) were stained with $1 \%$ methylene blue-1\% azure II. Direct measurements of cross-sectional areas of endometrium and whole uteri were made using a computerized image analyser (Bioquant II Image Analysis) as previously described (Chilton \& Daniel, 1987).

For immunocytochemistry, small pieces (2-3-mm long) of whole tissue were quick frozen in liquid nitrogen, mounted in Tissue-Tek O.C.T. compound and sectioned $(3 \mu \mathrm{m})$. Sections were mounted on uncoated glass slides and stored at $-80^{\circ} \mathrm{C}$. Immunolocalization of oestrogen and progesterone receptors was accomplished with monoclonal antibodies H222 and JZB39, respectively, provided by Abbott Laboratories, Diagnostic Division (Abbott Park, IL, USA), and Dr G. Greene, Ben May Laboratories for Cancer Research, University of Chicago (Chicago, IL, USA). Slides were warmed to room temperature, fixed immediately (1\% paraformaldehyde), permeabilized with $85 \%$ ethanol, rinsed with PBS and preincubated with normal rabbit serum (NRS) for $30 \mathrm{~min}$ at room temperature. Tissue sections were subsequently incubated with H222 $(7 \cdot 2 \mu \mathrm{g} / \mathrm{ml})$ or JZB39 $(9 \cdot 2 \mu \mathrm{g} / \mathrm{ml})$ overnight in a moist chamber at $4^{\circ} \mathrm{C}$ as described by West et al. (1987). At 16-24 h later, tissue sections were rinsed with PBS, preincubated with NRS and then incubated with reagents from a Vectastain ABC Kit (PK-4004, Vector Laboratories, Burlingame, CA, USA) according to the manufacturer's instructions. The substitution of NRS for primary monoclonal antibody constituted the control.

Immunolocalization of prolactin receptor was accomplished with the monoclonal antibody M110 to the rabbit mammary gland prolactin receptor (Katoh et al., 1985) provided by Dr Paul Kelly (Royal Victoria Hospital, Laboratory of Molecular Endocrinology, Montreal, Quebec, Canada). As described above, sections were fixed briefly ( $1 \%$ paraformaldehyde), rinsed with PBS, and preincubated with normal horse serum (NHS) for $30 \mathrm{~min}$ at room temperature. Tissue sections were subsequently incubated with the monoclonal antibody $\mathrm{M} 110(10 \mu \mathrm{g} / \mathrm{ml})$ overnight in a moist chamber at $4^{\circ} \mathrm{C}$. At 16-24 h later, tissue sections were rinsed with PBS, preincubated with NHS and then incubated with reagents from a Vectastain ABC Kit (PK-4002) according to the manufacturer's instructions. The substitution of NHS for primary monoclonal antibody constituted the control. For all of the immunocytochemical studies, tissue sections were photographed and relative intensities of immunostained cells were quantified with a computer-assisted image analysis system (Bio-Image Visage 2000, Eastman Kodac Co., Ann Arbor, MI, USA). 
Ratios of stain intensity (I) to area (A) were calculated for 10 cells in each region, i.e. epithelium, stroma and myometrium of an immunostained section from each animal. A mean value was calculated from each set of $10 \mathrm{I} / \mathrm{A}$ values. Mean values for a total of 8 animals per treatment category were then calculated (each value is a grand mean of 80 values) and listed in Table 3 .

RNA isolation and slot-blot analysis. Total RNA was isolated from $200-\mathrm{mg}$ samples of whole uteri according to Chirgwin et al. (1979). Detailed procedures for slot-blot hybridization of RNA with nick-translated pUG $11 \cdot 8$, a fulllength uteroglobin genomic clone (Snead et al., 1981), have been published (Chilton et al., 1988). Relative intensities of mRNA autoradiograms were quantified with a computer-assisted image analysis system (Bio-Image Visage 2000). Values are expressed as integrated optical densities.

Statistical analysis. Non-parametric data (uteroglobin protein and mRNA values) were analysed by the MannWhitney $U$ test $(P<0.05$ significance level). Parametric data were analysed by one-way analysis of variance (morphometric analysis), and two-way analysis of variance (immunostain data), followed by Duncan's multiple range test $(P<0.05$ significance level) using the SAS Statistics package (SAS Institute Inc., 1985). Values are expressed as mean \pm s.e.m. and those with the same letter designation are not significantly different $(P>0 \cdot 05)$.

\section{Results}

In this study, the antiserum to uteroglobin was from the collection made during the 3rd week of the immunization schedule, after absorption with serum from oestrous rabbits. Ouchterlony analysis provided the basis for selection of the antiserum whose monospecificity was established by two-dimensional immunoelectrophoresis (Randall, 1986).

Table 2 contains a summary of the treatment protocols as related to uteroglobin production. As shown, only juvenile rabbits treated with the oestradiol $(100 \mu \mathrm{g}) /$ prolactin/progesterone and with the oestradiol $(100 \mu \mathrm{g}) / \mathrm{sham}$ progesterone protocols produced detectable amounts of uteroglobin in their uterine flushings. The oestradiol/prolactin/progesterone group produced a mean value approximately 3 -fold greater than that of the oestradiol/sham progesterone group $(P=0.0829)$. Integrated optical density values, a measure of uteroglobin mRNA content, were significantly different $(P=0.0068)$. Values increased from $0.13 \pm 0.02$ for animals treated with oestradiol $(100 \mu \mathrm{g}) /$ sham progesterone to $0.29 \pm 0.05$ when prolactin was included in the protocol, i.e. animals treated with oestradiol $(100 \mu \mathrm{g}) /$ prolactin/progesterone. Prolactin treatment also enhanced the effect of progesterone by increasing the thickness of the uterine endometrium (Table 3 ).

Table 2. Treatment categories of neonatal rabbits

\begin{tabular}{|c|c|c|c|c|c|}
\hline \multirow[b]{2}{*}{ Group } & \multirow[b]{2}{*}{$\begin{array}{c}\text { Treatment } \\
\text { (hormones administered) }\end{array}$} & \multicolumn{2}{|c|}{ 9-day-old rabbits } & \multicolumn{2}{|c|}{ 22-day-old rabbits } \\
\hline & & No. & $\begin{array}{l}\mathrm{mg} \text { uteroglobin } / \mathrm{mg} \\
\text { total protein }\end{array}$ & No. & $\begin{array}{l}\text { mg uteroglobin } / \mathrm{mg} \\
\text { total protein }\end{array}$ \\
\hline 1 & None (control) & 7 & ND & 3 & ND \\
\hline 2 & Oestradiol $(10 \mu \mathrm{g})$ alone & 5 & ND & 3 & ND \\
\hline 3 & Oestradiol $(10 \mu \mathrm{g})+$ prolactin & 5 & ND & 3 & ND \\
\hline 4 & $\begin{array}{l}\text { Oestradiol }(10 \mu \mathrm{g})+\text { prolactin }+ \\
\text { progesterone }\end{array}$ & 4 & ND & 5 & ND \\
\hline 5 & Oestradiol $(10 \mu \mathrm{g})+$ progesterone & 7 & ND & 4 & ND \\
\hline 6 & Oestradiol $(100 \mu \mathrm{g})$ alone & 3 & ND & 4 & ND \\
\hline 7 & Oestradiol $(100 \mu \mathrm{g})+$ prolactin & 3 & ND & 4 & ND \\
\hline 8 & $\begin{array}{l}\text { Oestradiol }(100 \mu \mathrm{g})+\text { prolactin }+ \\
\text { progesterone }\end{array}$ & 11 & ND & 6 & $0.098 \pm 0.031$ \\
\hline 9 & Oestradiol $(100 \mu \mathrm{g})+$ progesterone & 5 & ND & 4 & $0.034 \pm 0.010$ \\
\hline 10 & Prolactin alone & 6 & ND & 4 & ND \\
\hline 11 & Prolactin + progesterone & 5 & ND & 5 & ND \\
\hline 12 & Progesterone alone & 10 & ND & 5 & ND \\
\hline
\end{tabular}

$\mathrm{ND}$, not detectable $(<0.01 \mathrm{mg})$. 
Table 3. Endometrial thickness and uterine localization of receptors in 22-day-old rabbits (values are expressed as mean \pm s.e.m., for 8 animals)

\begin{tabular}{|c|c|c|c|c|c|}
\hline \multirow{2}{*}{$\begin{array}{l}\text { Treatment } \\
\text { (hormones administered) }\end{array}$} & \multirow{2}{*}{$\begin{array}{l}\text { Endometrial } \\
\text { thickness } \\
\left(\mathrm{mm}^{2}\right)^{*}\end{array}$} & \multicolumn{3}{|c|}{$\begin{array}{l}\text { Receptor immunolocalization } \\
\text { [ratio of intensity (I) to area (A)] }\end{array}$} & \multirow{2}{*}{$\begin{array}{l}\text { Uterine } \\
\text { region }\end{array}$} \\
\hline & & Oestrogen & Progesterone & Prolactin & \\
\hline None (control) & $0.51 \pm 0.03^{a}$ & $\begin{array}{l}0.161 \pm 0.020 \\
0.062 \pm 0.006 \\
0.158 \pm 0.022\end{array}$ & $\begin{array}{l}0.581 \pm 0.042 \\
0.104 \pm 0.011 \\
0.159 \pm 0.013\end{array}$ & $\begin{array}{l}0.279 \pm 0.032 \\
0.083 \pm 0.006 \\
0.363 \pm 0.048\end{array}$ & $\begin{array}{l}\text { Epithelium } \\
\text { Stroma } \\
\text { Myometrium }\end{array}$ \\
\hline $\begin{array}{l}\text { Oestradiol }(100 \mu \mathrm{g})+ \\
\text { progesterone }\end{array}$ & $3 \cdot 11 \pm 0 \cdot 13^{b}$ & $\begin{array}{l}0.157 \pm 0.030 \\
0.046 \pm 0.004 \\
0.087 \pm 0.015\end{array}$ & $\begin{array}{l}0.256 \pm 0.051 \\
0.071 \pm 0.011 \\
0.119 \pm 0.020\end{array}$ & $\begin{array}{l}0.120 \pm 0.006 \\
0.051 \pm 0.006 \\
0.151 \pm 0.016\end{array}$ & $\begin{array}{l}\text { Epithelium } \\
\text { Stroma } \\
\text { Myometrium }\end{array}$ \\
\hline $\begin{array}{l}\text { Oestradiol }(100 \mu \mathrm{g})+ \\
\quad \text { prolactin }+ \text { progesterone }\end{array}$ & $4 \cdot 32 \pm 0 \cdot 35^{c}$ & $\begin{array}{l}0.199 \pm 0.027 \\
0.052 \pm 0.006 \\
0.166 \pm 0.030\end{array}$ & $\begin{array}{l}0.253 \pm 0.061 \\
0.054 \pm 0.006 \\
0.105 \pm 0.018\end{array}$ & $\begin{array}{l}0.289 \pm 0.050 \\
0.070 \pm 0.007 \\
0.267 \pm 0.034\end{array}$ & $\begin{array}{l}\text { Epithelium } \\
\text { Stroma } \\
\text { Myometrium }\end{array}$ \\
\hline
\end{tabular}

*Values with different superscript letters are significantly different $(P<0.01)$.

The effects of prolactin on endometrial histology were accompanied by changes in immunolocalization of receptor proteins as summarized in Table 3. Immunostaining for the nuclear oestrogen receptor was light in untreated control tissue with most of the immunoreactive receptor localized in the epithelium and myometrium. Immunostaining in the myometrium was reduced $(P<0.05)$ for oestradiol/sham progesterone-treated animals. When prolactin was administered, immunostaining for the oestrogen receptor in the myometrium returned to control levels (Table 3), but immunostaining in the epithelium and stroma did not change significantly in response to either treatment.

Because a dynamic relationship exists between prolactin and progesterone and their receptors in regulating uteroglobin gene expression in the adult uterus (Chilton et al., 1988), the effects of the treatments on progesterone and prolactin receptor expression were of particular interest. As shown in Table 3 and Fig. 1(a), intense immunostaining for nuclear progesterone receptor was localized in the epithelial cells of 22-day-old untreated animals. Staining was negligible for control sections (Fig. 1b), i.e. no I/A values were recorded for control sections when scanned with the Visage 2000. When animals were treated sequentially with oestradiol \pm prolactin + progesterone there was a decrease $(P<0.0001)$ in the intensity of immunostaining for the progesterone receptor in the epithelial cells (Table 3; Figs 1c \& d). The myometrium and stroma were unaffected by this treatment.

Immunostaining for prolactin receptor was most intense in the epithelium and myometrium of untreated animals (Table 3; Fig. 2a), and negligibly expressed in control sections (Fig. 2b). As described before, no I/A values were obtained with the image analysis system. When animals were injected with oestradiol/sham progesterone (Table 3; Fig. 2c), immunostain intensity was reduced $(P<0.0001)$ in the epithelium and myometrium. However, when prolactin was included in the injection regimen, immunostaining for the prolactin receptor returned to control levels for these two regions (Table 3; Fig. 2d). The stroma was unaffected by either treatment.

\section{Discussion}

The receptor-mediated interaction between prolactin and steroids in the regulation of uteroglobin gene expression is well documented for adult rabbits (Daniel et al., 1984, 1988; Chilton \& Daniel, 1985, 1987; Chilton et al., 1988). However, little is known about the tissue distribution, cellular content or biological activity of receptors in the juvenile rabbit uterus in which subtle differences in the interactions of hormones could have a dramatic effect on target organ development. Here we 

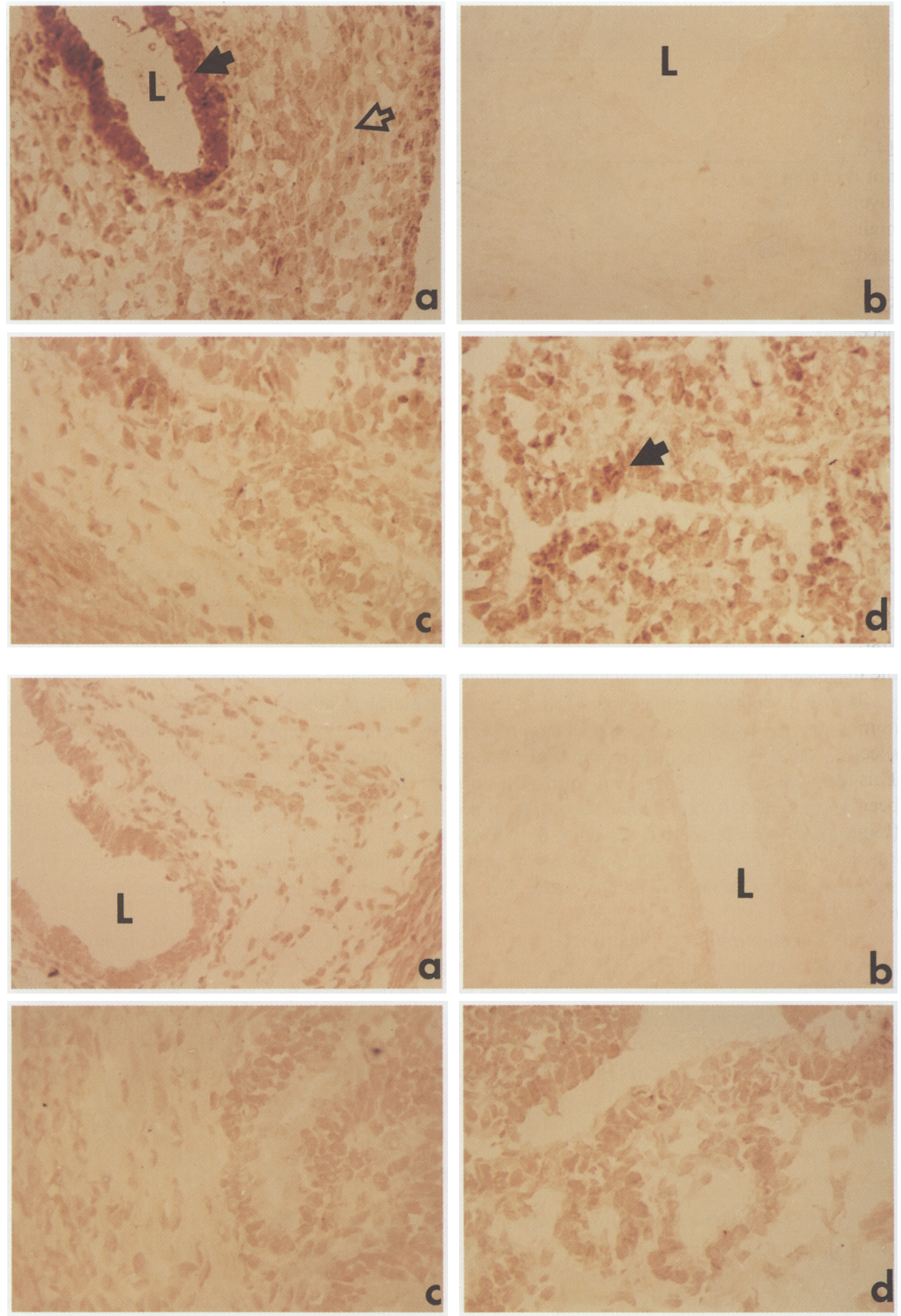
demonstrate that the rabbit uterus is competent to produce uteroglobin, in response to exogenous steroids, at an earlier age than heretofore reported, and that this response is enhanced by the addition of prolactin which increases the uteroglobin mRNA content of the tissue.

Booher \& Daniel (1977) reported detectable amounts of uteroglobin in uterine fluids as early as 26 days after birth in rabbits treated with progesterone alone for 5 days. In the present study, 14-day-old rabbits given progesterone alone did not produce uteroglobin and neonatal animals did not respond to any of the hormone treatments as measured by uteroglobin production. However, juvenile rabbits (14 days old) produced detectable amounts of uteroglobin after treatment with high doses of oestrogen followed by progesterone. Juveniles given the oestrogen dose normally

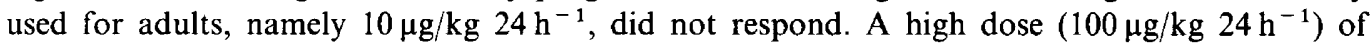
oestradiol was necessary to stimulate uterine secretory function. This supports the contention of Somjen et al. (1973) and Katzenellenbogen \& Greger (1974) that elevated oestrogen treatment is necessary to stimulate uterine function during early post-natal development.

A partial explanation of our result is provided by the fact that the amount of oestrogen receptor in juvenile rabbit uteri is significantly reduced and represents only $32 \%$ of the value for adult endometrium (Chilton et al., 1987). Moreover, an increase in steroid-receptor dissociation is correlated with a reduced rate of activation of steroid-receptor complexes (Chilton et al., 1987), thus limiting the biological effect of oestrogen on this undifferentiated tissue. The effect of progesterone is presumably compromised by the reduced progesterone receptor content of uteri from 1-, 2- and 4-week-old rabbits, i.e. receptor concentrations were $33-54 \%$ of the value for adult endometrium (B. S. Chilton, unpublished data). However, in testing the servomechanism hypothesis in these young animals, we demonstrated that the inclusion of prolactin in the treatment protocol amplified the uterine response to progesterone, resulting in an increase in the concentration of uteroglobin mRNA and the amount of secreted protein. Because uterine epithelial cells synthesize and secrete uteroglobin (Warembourg et al., 1986) we wanted to evaluate the receptor content of this region of the uterus.

The biochemical assays for steroid hormone receptors described above required whole tissue homogenates. Because this approach precludes attempts at defining the distribution of receptors in specific regions of the uterus we used an immunocytochemical approach to receptor localization. This work was expedited by the availability of well characterized monoclonal antibodies that have been used to detect oestrogen and progesterone receptors in various target organs of the rabbit (King \& Greene, 1984; Perrot-Applanat et al., 1988; Press \& Greene, 1988) and a monoclonal antibody to the rabbit mammary prolactin receptor (Katoh et al., 1985).

As summarized in Table 3, most of the oestrogen receptor in the juvenile uterus is localized in the epithelium and myometrium, while most of the progesterone receptor is localized in the epithelium. These immunocytochemical data confirm that the developing uterus is differentially

Fig. 1. Immunostaining for the nuclear progesterone receptor in a tissue section from a 22-dayold, untreated control animal (a). Staining is most intense in the epithelium (dark arrow), and reduced in intensity in stromal cells and cells that comprise the loosely organized myometrium (open arrow). Staining is negligible when non-immune serum is substituted for the monoclonal antibody (b). For both (a) and (b) the lumen (L) is indicated. Immunostaining is reduced in epithelial cells from animals treated with oestradiol sham progesterone (c) and from animals treated with oestradiol/prolactin/progesterone (d). $\times 200$.

Fig. 2. Immunostaining for the prolactin receptor in a tissue section from a 22-day-old, untreated control animal (a) is most intense in the epithelium and myometrium. Staining is absent when non-immune serum is substituted for the monoclonal antibody (b). For both (a) and (b) the lumen (L) is indicated. Immunostaining is reduced in intensity in epithelium and myometrium when animals are treated with oestradiol/sham progesterone (c). Immunostaining for the prolactin receptor is enhanced in epithelial cells when prolactin is included in the treatment protocol (d). $\times 200$. 
sensitive to steroid stimuli, a factor which could explain why the number of receptor sites per cell, as determined by biochemical assay, does not always correlate with the response of the juvenile uterus to steroid challenge (Pasqualini et al., 1983). Changes in the tissue distribution of receptor could play a key role in target organ development.

Prolactin receptor is present in low concentrations in the uteri of juvenile rabbits, and increases significantly during differentiation and sexual maturation (Chilton et al., 1988). It is now known (Table 3) that prolactin receptor is concentrated in the cells of the epithelium and myometrium, supporting the suggestion that these regions of the juvenile uterus are more sensitive to the action of prolactin during development than are stromal cells. In fact, when juvenile rabbits were treated sequentially with oestrogen and progesterone, changes in immunostaining for both prolactin and progesterone receptors were most profound in the epithelial cells. Chilton et al. (1988) have demonstrated that the inclusion of oestrogen in the treatment of long-term ovariectomized adult rabbits results in a decrease in prolactin receptor, whereas the inclusion of progesterone results in an increase in prolactin receptor. It is now important to use immunocytochemistry to determine how receptor values change within specific regions of the hormonally-manipulated adult uterus.

When prolactin was included in the protocol, prolactin receptor amounts in the epithelium and myometrium, and oestrogen receptor levels in the myometrium were not reduced in response to progesterone; rather they remained at control values. Perhaps prolactin treatment blocks the down regulation of steroid receptors. This idea is supported by the fact that prolactin treatment is known to increase the equilibrium association constant for the oestrogen receptor (Chilton \& Daniel, 1985). Furthermore, in the juvenile uterus prolactin seems to autoregulate its own receptor, an observation supported by our prior work with adult rabbits (Chilton et al., 1988).

Prolactin is involved at the morphological as well as at the biochemical level in modulating the uterine response to progesterone. Prolactin treatment of long-term ovariectomized rabbits results in increased endometrial cross-sectional area relative to whole uterus (Chilton \& Daniel, 1987). This change is accompanied by the appearance of endometrial glands and dramatic changes in the ultrastructural characteristics of the epithelial cells, indicating that they are active in protein synthesis and secretion (Chilton \& Daniel, 1985). It is now apparent that prolactin treatment of juvenile rabbits supports the action of oestrogen + progesterone in increasing endometrial cross-sectional area. Additional studies are required to define the effects of prolactin on the ultrastructural characteristics of the epithelial cells. Collectively, these data support the conclusion that prolactin enhances the action of progesterone in the juvenile uterus and provide the foundation for further investigations on the role of prolactin in uterine differentiation.

We thank Mr F. D. McAfee and Dr L. S. Geis for excellent technical assistance; and Dr M. L. Pan for technical advice and constructive criticism. This work was supported by NIH grant HD20271 (JCD, BSC). B.S.C. is the recipient of NIH RCDA HD-00704.

\section{References}

Booher, C.B. \& Daniel, J.C. (1977) Synthesis of the rabbit uterine protein, Blastokinin: Onset and age dependent changes. J. Tenn. Acad. Sci. 52, 37-39.

Chilton, B.S. \& Daniel, J.C. (1985) Influence of prolactin on DNA synthesis and glandular differentiation in rabbit uterine endometrium. In Prolactin Basic and Clinical Correlates, Vol. 1, pp. 351-359. Eds R. M. MacLeod, M. O. Turner \& L. Scapagnini. Livianna Press, Pavoda.

Chilton, B.S. \& Daniel, J.C. (1987) Differences in the rabbit uterine response to progesterone as influenced by growth hormone or prolactin. J. Reprod. Fert. 79, $581-587$.
Chilton, B.S., Williams, N.D., Cobb, A.D. \& Leavitt, W.W. (1987) Ligand-receptor dissociation: A potential mechanism for the attenuation of oestrogen action in the juvenile rabbit uterus. Endocrinology 120, $750-757$.

Chilton, B.S., Mani, S.K. \& Bullock, D.W. (1988) Servomechanism of prolactin and progesterone in regulating uterine gene expression. Molec. Endocrinol. 2, 1169-1175.

Chirgwin, J.M., Przbyla, A.E., MacDonald, R.J. \& Rutter, W.J. (1979) Isolation of biologically active ribonucleic acid from sources enriched in ribonuclease. Biochemistry, NY 18, 5294-5299. 
Crowle, A.J. (1973) Immunodiffusion, 2nd edn, pp. 247-402. Academic Press, New York.

Daniel, J.C. (1976) Blastokinin and analogous proteins. J. Reprod. Fert., Suppl. 25, 71-83.

Daniel, J.C. \& Juneja, S.C. (1989) Amplification of uteroglobin secretion by alternating prolactin-progesterone administration. J. Endocr. 122, R5-R6.

Daniel, J.C., Jetton, A.E. \& Chilton, B.S. (1984) Prolactin as an essential factor in the uterine response to progesterone. J. Reprod. Fert. 72, 443-452.

Daniel, J.C., Juneja, S.C., Taylor, S.P., Lonergan, P.B., Sullivan, P.K. \& Chilton, B.S. (1988) Variability in the response of the rabbit uterus to progesterone as influenced by prolactin. J. Reprod. Fert. 84, 13-21.

Gibori, G., Richards, J.S. \& Keyes, P.L. (1979) Synergistic effects of prolactin and oestradiol in the luteotropic process in the pregnant rat: regulation of oestradiol receptor by prolactin. Biol. Reprod. 21, 419-423.

Hammond, J.M. \& Krall, E. (1979) Steroid hormones modulate prolactin binding by cultured porcine granulosa cells. Biochem. Biophys. Res. Commun. 91, 284-288.

Johnson, M.H., Cowan, B.D. \& Daniel, J.C. (1972) An immunological assay for blastokinin. Fert. Steril. 23, 93-100.

Katoh, M., Djiane, J. \& Kelly, P.A. (1985) Monoclonal antibodies against rabbit mammary prolactin receptors. J. biol. Chem. 260, 11422 11429.

Katzenellenbogen, B.S. \& Gregor, N.G. (1974) Ontogeny of uterine responsiveness to oestrogen during early development in the rat. Molec. cell. Endocr. 2, 31-42.

King, W.J. \& Greene, G.L. (1984) Monoclonal antibodies localize receptor in the nuclei of target cells. Nature, Lond. 307, 745-747.

Lowry, O.H., Rosebrough, N.J., Farr, L.A. \& Randall, R.J. (1951) Protein measurement with the folin phenol reagent. J. biol. Chem. 193, 265-275.

Luft, J.H. (1961) Improvements in epoxy resin embedding methods. J. Biophys. Biochem. Cytol. 9, 409414.
Pasqualini, J.R., Sumida, C. \& Gulino, A. (1983) Receptors and biological responses to ovarian steroid hormones in the fetal and perinatal periods. In International Review of Physiology, vol. 27, pp. 225-273. Ed. R. O. Greep. University Park Press, Baltimore.

Perrot-Applanat, M., Groyer-Picard, M.T., Garcia, E., Lorenzo, F. \& Milgrom, E. (1988) Immunocytochemical demonstration of oestrogen and progesterone receptors in muscle cells of uterine arteries in rabbits and humans. Endocrinology 123, 1511-1519.

Press, M.F. \& Greene, G.L. (1988) Localization of progesterone receptor with monoclonal antibodies to the human progestin receptor. Endocrinology 122, 1165-1175.

Randall, G.W. (1986) Prolactin-enhanced uteroglobin synthesis and secretion by uteri of oestrogen and progesterone treated juvenile rabbits. Ph.D. thesis, The University of Tennessee, Knoxville, TN.

SAS Institute Inc. (1985) Users Guide: Statistics Version 5 edition, pp. 113-138. SAS Institute Inc, Cary, NC.

Snead, R., Day, L., Chandra, T., Mace, M., Jr, Bullock, D.W. \& Woo, S.L.C. (1981) Mosaic structure and mRNA precursors of uteroglobin a hormoneregulated mammalian gene. J. biol. Chem. 256, 11911-11916.

Somjen, D., Somjen, G., King, R.J.B., Kaye, A.M. \& Lindner, H.R. (1973) Nuclear binding of oestradiol$17 \beta$ and induction of protein synthesis in the rat uterus during postnatal development. Biochem. J. 136, 25-33.

Warembourg, M., Tranchant, O., Atger, M. \& Milgrom, E. (1986) Uteroglobin messenger ribonucleic acid: localization in rabbit uterus and lung by in situ hybridization. Endocrinology 119, 1632-1640.

West, N.B., McClellan, M.C., Sternfeld, M.D. \& Brenner, R.M. (1987) Immunocytochemistry versus binding assays of the oestrogen receptor in the reproductive tract of spayed and hormone-treated macaques. Endocrinology 121, 1789-1800.

Received 9 May 1990 